\title{
Air Basins of Rio de Janeiro State, Brazil
}

\author{
Rafael S. Barboza1, Ricardo Valcarcel ${ }^{1 *}$, Ednaldo 0. Santos ${ }^{1}$, Carlos R. Pereira ${ }^{2}$ \\ ${ }^{1}$ Laboratory of Catchment Basins Management, Department of Environmental Sciences, Forestry Institute, \\ Federal Rural University of Rio de Janeiro, Seropédica, Brazil \\ ${ }^{2}$ Department of Agricultural Engineering and Environment, School of Engineering, Fluminense Federal \\ University, Niteroi, Brazil \\ Email: rafael.floresta@gmail.com, ${ }^{*}$ ricval@ufrri.br, edmeteoro@ufrri.br, crpereira@vm.uff.br
}

Received 16 March 2015; accepted 14 July 2015; published 17 July 2015

Copyright (C) 2015 by authors and Scientific Research Publishing Inc.

This work is licensed under the Creative Commons Attribution International License (CC BY). http://creativecommons.org/licenses/by/4.0/

(c) (i) Open Access

\section{Abstract}

The air basin is a three-dimensional space which conducts and distributes winds over the catchment basins. In the state of Rio de Janeiro $\left(43,305 \mathrm{~km}^{2}\right), 48 \%$ of the territory comprises the Atlantic slopes (the windward side) and $52 \%$ (the leeward side) suffers the influence of the Atlantic Ocean. On the windward side, $20 \%$ of the area includes 16 air basins, which influence the movement of humid air currents, affecting all of the windward regions and environmentally conditioning the leeward areas. The morphometric parameters of these air basins have been characterized: area of influence upwind ( 4 parameters), slope ( 5 parameters), and distribution zone (5 parameters), and they are grouped together in 5 units by similar functional identity, utilizing multivariable analysis, cluster method, with a Euclidian distance of $48 \%$, significance level of $95 \%$, and correlation coefficient of $\mathbf{0 . 7 1 3 2}$. The management of environmental services within the hydrographic basins where 16 million people live is conditioned by these air basins, which could have their environmental planning perfected by this knowledge.

\section{Keywords}

Landscape, Fog Interception, Water Resources, Watershed

\section{Introduction}

Climate is among the innumerous components of the landscape which comprise the environmental characteristics of a region [1]. Consequently, the knowledge of its interactions with the other elements of the environment is essential for any activity. For comprehension of the atmospheric dynamics, it is necessary to consider largescale phenomenon, mesoscale disturbances (regional or secondary circulation), local conditions of a varied na-

"Corresponding author. 
ture (biogeoclimatic, topographic) and dynamic interactions [2]-[4].

In South America, atmospheric circulation depends on ocean conditions, high and low pressure centers, and disturbances which influence the tropical systems (humidity convergence zone from the Amazon, circulation of the Bolivian high-pressure zone) and extra-tropical systems [5] [6]. These mechanisms cause the atmospheric conditions to vary throughout the year, also being affected systems of cold air masses, which contrast with the warm and humid air masses, coming from the Intertropical Convergence Zone (ITCZ). These all suffer local influences from land relief [7]-[9].

Figueroa and Nobre [10] pointed out the role of the Andes Mountains in the formation of precipitation, both from induction, due to the effects of the mechanical raising of humid winds and the refinement of the orographic effect, as well as from the blockage of accesses in a regionalized way.

Atmospheric dynamics influence the climate of micro-regions on different scales [8] [9] [11], being a determinant factor in regional planning. Evidently, other bio-geographical factors (latitude, altitude, land-cover and land-use change) are fundamental parameters in climate studies, because the anthropogenic activities, modifying the landscape, impose diversification of land use, relief, and influence the mass and energy balances (for example, water vapor, sensible heat, latent heat) [6] [12] [13].

So, the discovery of the habitual succession of atmospheric systems in a determined region and the understanding of its repercussions in each specific meteorological system constitute fundamental factors for verifying its impact on a geographic space [14], mainly rainfall, whose special distribution and temporal regularity interfere in the environmental planning [9] [11]: agronomic activities; water supply; power generation; and physical and biological processes within the ecosystems.

The air basins are considered to be three-dimensional spaces from the time-space point of view, because they include the hydrological characteristics of the ecosystems, human activities, and are part of the catchment basins, comprising units of environmental planning, and are capable of being used for monitoring and managing air quality [15] [16] and water production. Since they are superimposed on the catchment basins, influence their management, affect air flows and the differentiated supply of environmental attributes, principally in locations where orographic effects are prominent, such as in the roles of vegetation, evapotranspiration, plant interception of rainfall and production of water vapor and/or rainfall [17]-[19] in regional water balances.

Regional atmospheric circulation and the movement of cold fronts suffer marked interference from winds coming from the southwest or northeast in this region, influencing daily temperatures and precipitation patterns [7] [15] [20] [21]. The orientation and exposition of relief interfere in the spatial distribution of rainfall, both in its intensity and frequency, which effects are enhanced by the higher altitude in the south-central region of the state [9] [10] [21]. Thus, in the regional conditions, these relationships exist and must be improved [22].

The present study proposes to classify the air basins of the Brazilian state of Rio de Janeiro, identifying, characterizing and grouping according to similar environmental attributes, based on their different morphometric factors which have environmental significance.

\section{Material and Methods}

\subsection{Study Area}

The state of Rio de Janeiro (latitudes $20^{\circ} 45^{\prime} \mathrm{S}$ to $23^{\circ} 21^{\prime} \mathrm{S}$; longitudes $40^{\circ} 57^{\prime} \mathrm{W}$ to $44^{\circ} 53^{\prime} \mathrm{W}$ ), located in the southeast region of Brazil, where the Serra do Mar mountain chain is found (Figure 1), is divided into the windward area (Coastal Zone) and the leeward area (the watershed or catchment basin of the Paraíba do Sul river).

The predominant climatic types, according to Thornthwaite and Mather [23] are the Superhumid, on the seaward slopes, and the Mesothermic, on the opposite sides, at the base of the Serra do Mar and in the Paraíba Valley, where the temperatures are low, differing from each other thermally. The climate is tropical humid, with a rainy season in summer (December to April) and a dry season in winter (June to August) [24]. The dry season is only slightly pronounced, with variations in precipitation occurring in function of the relief. The average annual precipitation is $1200 \mathrm{~mm}$ and the main temperature is $24^{\circ} \mathrm{C}$ [25].

\subsection{Methodology}

Taking into consideration the influences of the topography and meteorology on the dispersive capacity of atmospheric pollutants, four air basins have been delimited in the metropolitan region of Rio de Janeiro [15] [26], 


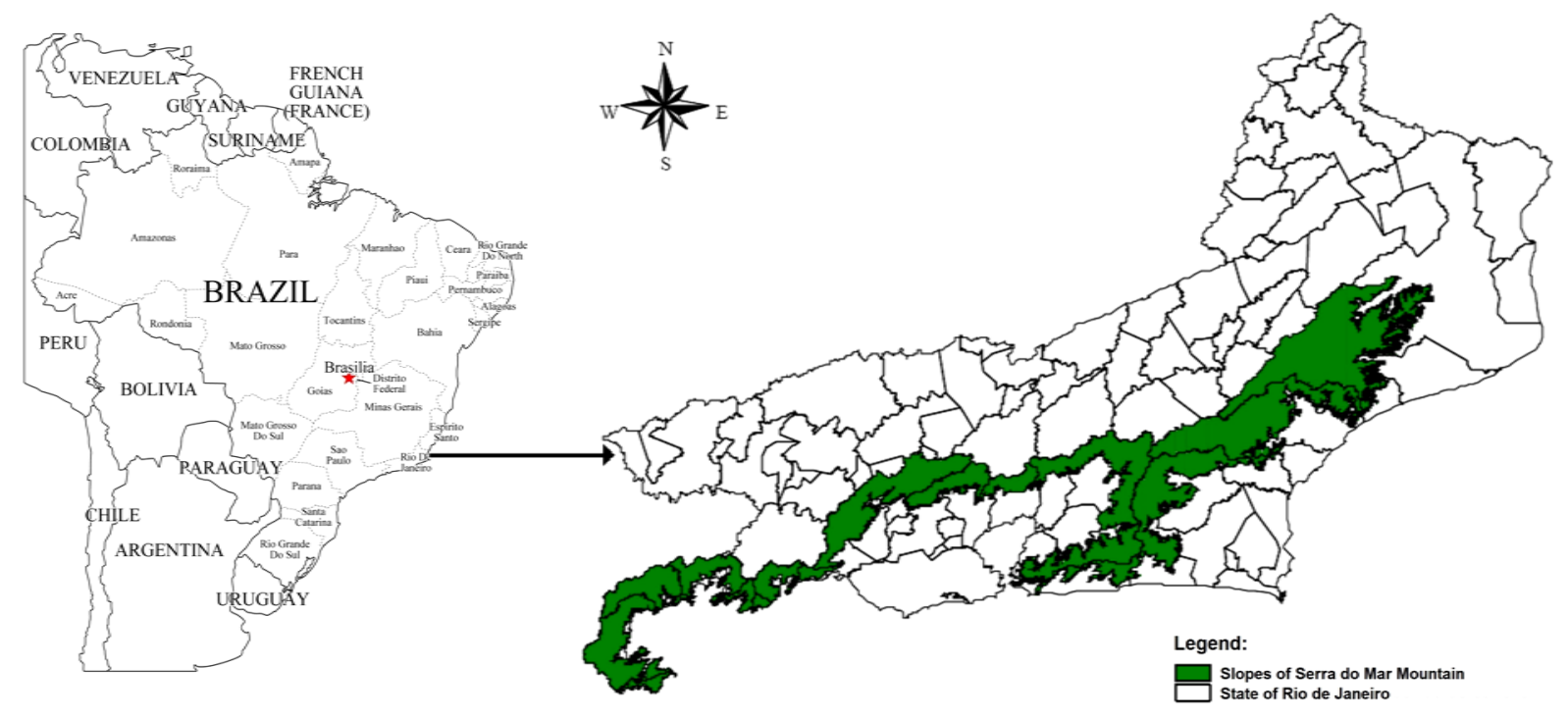

Figure 1. Study area, Rio de Janeiro, Brazil.

utilizing an altitude range of $100 \mathrm{~m}$ from the upper limit of the air basin. In the present study, all the orographic barriers were considered, varying from sea level to the crest line.

The air basins were divided on the mountain chain according to the main channels of air circulation from the ocean towards the interior. They were described on the basis of their morphometry, utilizing variables from the physical environment (landforms, interception areas and total area, and size of the basin's mouth) as well as factors which limit the direction and interception of the winds to their free movement (distance from the Atlantic Ocean and degrees of obstruction).

This study used 36 digital maps (scale of 1:50,000) from IBGE (Brazilian Institute of Geography and Statistics), made available by the Geosciences Directory/Cartographic Coordination [27].

\subsection{Characterization of the Air Basins}

The air basins were divided into four sectors for characterization purposes of the landscape elements which interfere in the driving dynamics of the winds: 1) Area upwind of the air basin (Capture); 2) Slopes: from the base to the divide (Conduction); 3) Escape Area: Interfluve-upper basin; and 4) Distribution, described below (Figure 2).

The measure for defining of the parameters that condition the passage of air currents (Figure 3) into Capture, Conduction and Escape Zones of the winds was determined based on data for the direction and intensity of wind flow (volume, intensity and frequency), obtained by network rainfall stations [28].

\subsubsection{Area of Influence Upwind of the Air Basin (Capture)}

Area between the Atlantic Ocean and the Serra do Mar mountains, involving the region up to the beginning of the flow alteration zone/beginning of the rise (foothills of the mountains or transition line of the relief). Additionally, other relevant parameters such as distances, elevations (altitudinal gradient), entrance angles and the relationship with the direction of cold fronts and breezes are fundamental for this delineation.

1) Entrance to the air basin (capture zone for humidity): variable which expresses cross section to the wind currents, through which the entire air mass is forced to enter the air basin. To delimit it spatially, a closed polygonal line was considered, similar to a trapezoid, where the larger base meets the line of intersection with the lateral walls in the flat area, situated upwind of the air basin (line EF), as shown in Figure 3. The smaller base, situated in the higher part was considered to be the line where there is an overlapping of the base line with the interfluve (line GH). The lateral walls consisted of the lines that connect the extremities of the low parts with the high parts, being the lines on the left and right sides (EG and FH). Thus, the entrance was defined by determining this area according to the polygonal figure which was adjusted as much as possible.

2) Distance from the area to the Atlantic Ocean (distance in meter-line AB): represents the projection of 


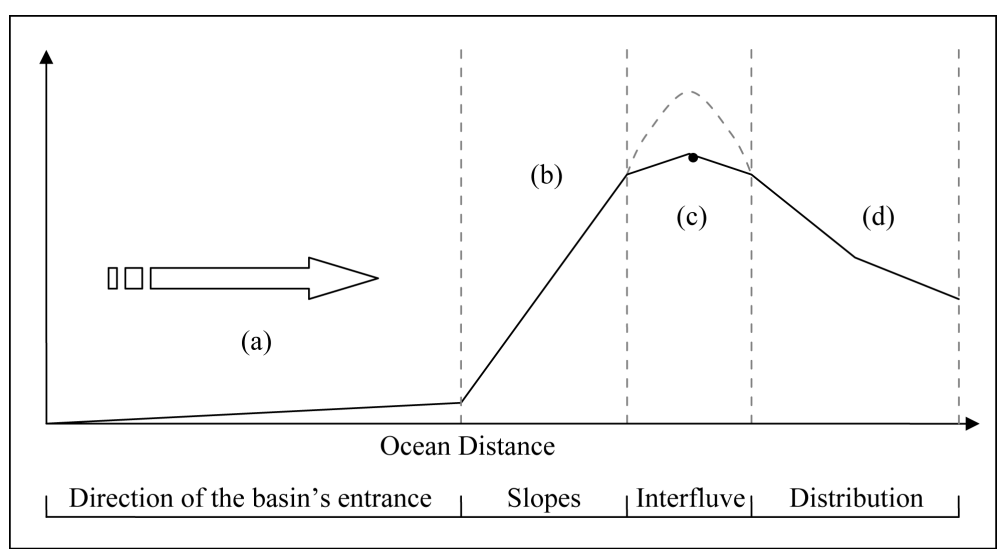

Figure 2. Longitudinal profile of the air basin, presenting the principal sectors which affect wind flow.

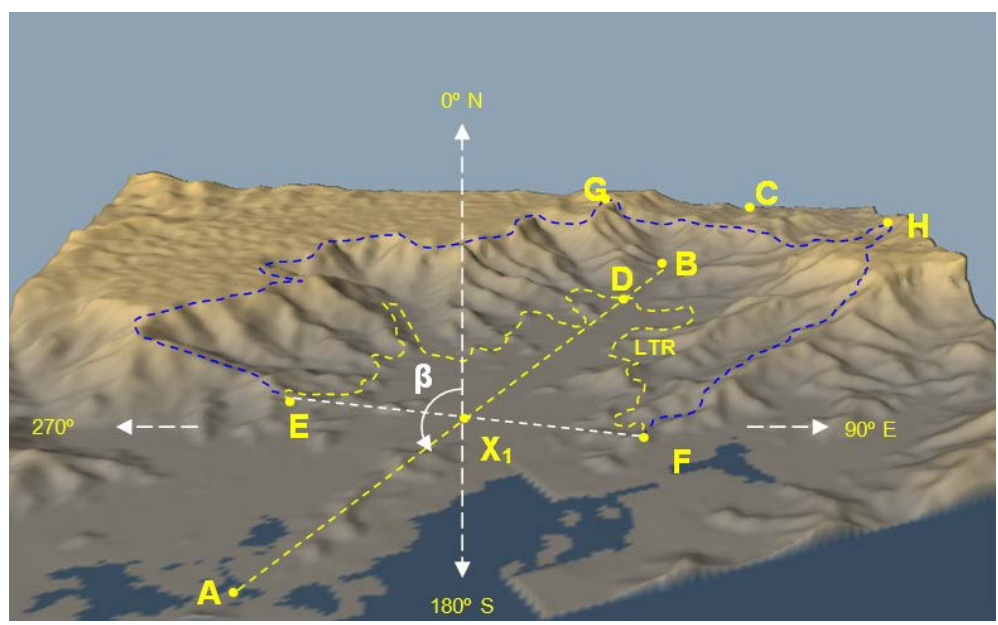

Figure 3. Schematic representation of the morphometric parameters of the air basin.

the distance traveled by the air mass from the Atlantic Ocean to the base of the air basin.

3) Transition line of the relief (LTR): this is considered as the point where the foothills begin, from the initial level to a level of positive value and the beginning of the entrance of the humidity. At the farthest point from the Atlantic Ocean, the land begins to rise (D).

4) Adopted rotation axis (X1 point): represents the orientation of the entrance (line EF) relative to true north. The distance to the Atlantic Ocean in relation to the line segment EF (interception line) is represented by segment AX1 (in meters). The variable X1D represents the distance from line segment EF in relation to the relief transition line (LTR) at half interfluve.

5) Degree of Convergence (represented by the LTR in relation to the variable X1): when the LTR occurs before X1, it means that the "capture zone for humidity" is convex at its base, dispersing humidity: if the LTR is after X1, it means that the entrance for humidity is concave at its base. The representation of this parameter is made using the Measure of the Degree of Convergence, which is obtained as follows:

$$
\mathrm{Cg}=\frac{\mathrm{X} 1 \times \mathrm{D}}{\mathrm{EF}}
$$

in which $\mathrm{Cg}=$ degree of convergence, $\mathrm{X} 1 \times \mathrm{D}=$ distance from line segment $\mathrm{EF}$ to the relief transition line (LTR) at half interfluve, and $\mathrm{EF}$ = width of the entrance for humidity.

Using Equation (1), the order of magnitude of convergence at the relief transition line is observed when:

Cg > 1 Convergence; 
$\mathrm{Cg}=1$ Level (LTR coincides with line EF);

$\mathrm{Cg}<1$ Divergence.

Thus, the degree of convergence characterizes the shape (concave, level or convex) or the format of the interception polygon.

Furthermore, the angle $(\alpha 1)$ between the projection in the middle of the topographic divide and its tangentis represented by Equation (2).

$$
\alpha 1=\frac{\mathrm{h}}{\mathrm{AD}}
$$

in which $\mathrm{h}=$ altitude of point $\mathrm{D}$, and $\mathrm{AD}=$ line segment which connects the ocean to the slope.

6) Line Orientation EF $(\beta)$ : angle between the North-South line, starting from the North, and the wind flow direction line within the air basin, indicating the air quality, in terms of humidity, to which the basin is exposed. The winds which flow through the air basin will have angles raging from $0^{\circ}$ to $360^{\circ}$ with reference to North $\left(0^{\circ}\right)$.

Depending on the line orientation EF, which characterizes the direction of the inlet basin, weights were established based on the concentration of the humidity (RH\%): Northeast: least humidity (weight of $0.3=30 \%$ ); Northwest: (weight $0.5=50 \%$ ); Southeast: (weight $0.7=70 \%$ ); and Southwest: high humidity (weight $1.0=$ 100\%), as shown in Figure 4. It must be emphasized that, especially in the state of Rio de Janeiro (Serra do Mar Mountains), the winds from Southwest are those which bring more humid air, thus favoring the hidden rainfall process produced by fog interception.

\subsubsection{Slopes}

The interfluve comprises the highest part of the air basin, and represents the terminal points of the orography in the wind flow, with the gorges being the places with a greater frequency of influence on the movement of air currents [13] [19]. This sector involves the slopes themselves, the inclinations, the terrain features, as well as the accumulation of humidity and the relationship with the less turbulent movements of the clouds caused by the wind [19].

Thus, the polygon EFGH (Figure 5) represents the mouth through which humidity enters, being the variable that measures the area (based on LTR) in which the wind is captured. It has area (closed polygonal figure, calculated specifically for each case), an inclination angle, a slope shape and a degree of convergence. The variable $\mathrm{BC}$, which interferes in the intensity of the orographic effect, represents the high point of each air basin.

The declivity (angle $\alpha 2$ ) refers to the effective interception zone, and the orographic effect is related to this angle. Thus, the larger the angle $\alpha 2$, the greater the orographic effect (interception) and the greater the accumulation of air.

Consequently, the shape of the slope is directly proportional to the degree of convergence CG (concave, level or convex). Weights with values of 3,2 and 1, respectively, may be attributed to each shape. A value of three (3) represents slopes with a concave pattern; a value of two (2) was attributed to slopes with a level format; and a value of one (1) was given to the slopes with a convex pattern. Thus, the values were attributed on the basis of

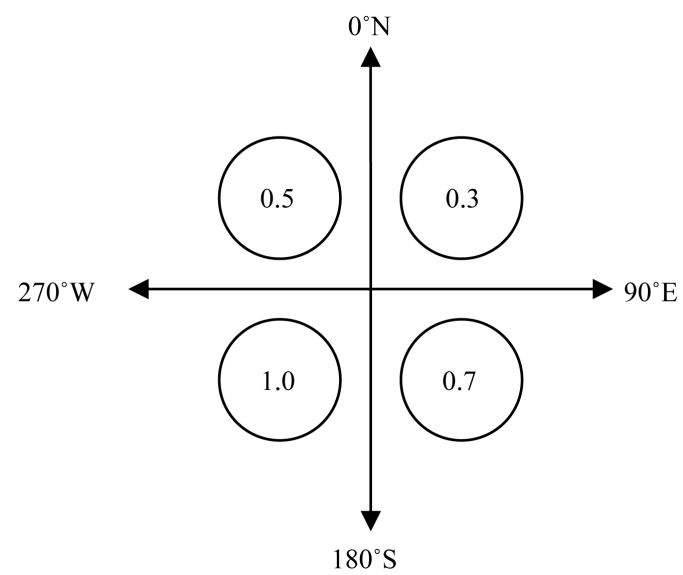

Figure 4. Weights attributed to wind directions. 
the accumulating capacity or dispersion of the humidity, ranging from 3 to 1.

Furthermore, the length of the slope in EF/2 is directly related to the average declivity of the slope, represented by the segment DC in Figure 5.

\subsubsection{Escape Areas at the Interfluve (Upper Basin)}

The escape zone of air basins represents the exit corridors of their air flow (Figure 6), where the flow mechanisms distribute it onto the leeward regions of the mountain chain.

As a result, these "air exit gorges" have been broken down into three parameters: 1) direction of the gorge, represented by the symbol $\theta$ the angle in relation to north, and that is directly influenced by the direction of the entrance of wind into the air basin; 2) width of the largest side of the trapezoid (gorge), represented by the segment CC', which refers to the distance between the two peaks which comprise the main gorge of the air basin; 3 ) the gorge length, represented by the connections between points Mo-oN (Figure 6), which refers to the area in which the effects of the air basin will influence the leeward region.

\subsubsection{Distribution}

Zone which is under the influence of the effects of the air basin, where the free circulation of wind, conditioned by the orographic effects constitutes a differential element in the formation of environmental attributes of the catchment basins to leeward of the mountain chain.

\subsection{Statistical Analysis of the Data}

The data were normalized using the ration attribute/sum, according to [29] [30]. Cluster by multivariate analysis was applied, using the Vegan pack [31] of the R software [32].

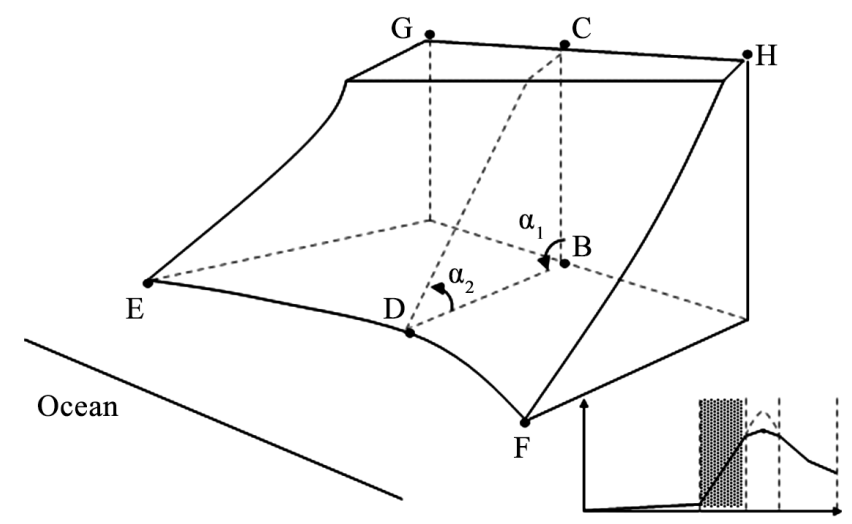

Figure 5. Conduction zone of air flow on slopes.
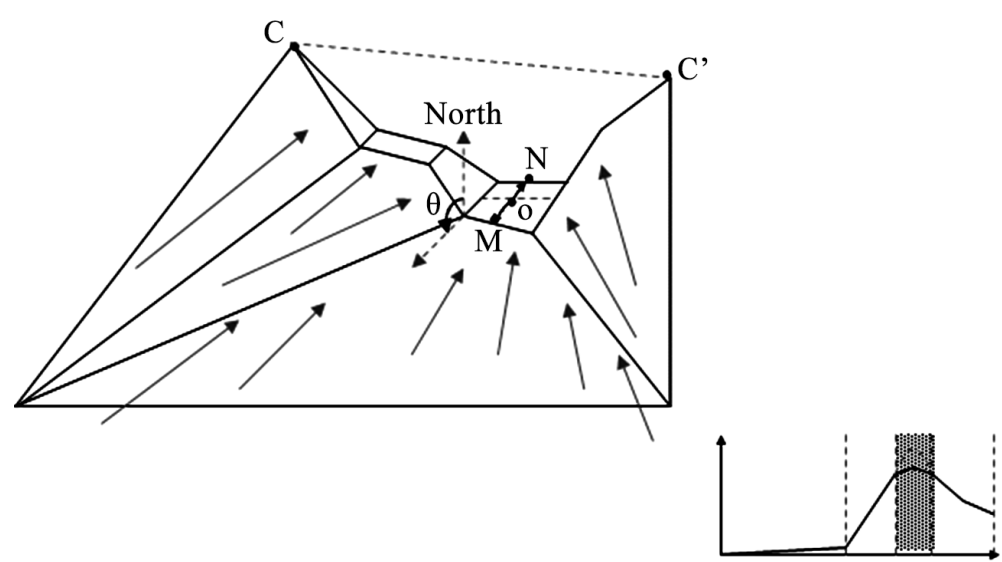

Figure 6. Escape zone of the air flow. 


\section{Results and Discussion}

Using the established methodology, 16 air basins have been identified in the state of Rio de Janeiro, from Trindade to Macabu (Figure 7), whose shapes, topographic and climatic characteristics are distinct and, consequently, affect the differentiated capture of winds in function of angle of inclination of the mouth of the air basin and distance from the Atlantic Ocean. These phenomena have regionalized spatial dimensions due to the chain of Serra do Mar Mountains have angles and distances variables regarding to the shape of the Atlantic coast.

\subsection{Characterization of the Air Basins in Rio de Janeiro State}

The total area of the 16 air basins is $11664.32 \mathrm{~km}^{2}$, whose individual sizes, considered small (between 0.15 to $\left.2.0 \mathrm{~km}^{2}\right)$, constitute $44 \%$ of the area studied, representing approximately $1 \%$ of the state's total area $\left(43,780 \mathrm{~km}^{2}\right)$ (Table 1). These results prove the importance of the small areas of the air basins and their great benefits for the populations which inhabit the lower sections of the catchment basins.

In $62 \%$ of these air basins, the areas showed a declivity ranging from $45 \%$ to $80 \%$, while $38 \%$ the declivity varied from $20 \%$ to $40 \%$, these being distributed along the mountains chain of Rio de Janeiro state (Table 1). The declivity combined with hydrological effects of the plant coverage, and the air flow velocity, enhances the formation of orographic rainfall [14] and of hidden rainfall from fog interception [33] within the catchment basins.

The concave shape of the slopes predominated in $56 \%$ of the air basins, showing the close relationship between the slopes and the troughs in the catchment basins, where the rivers and all types of flow which compose their hydrographs are found. Of the rest, 38\% of the air basins have level slope patterns, and $6 \%$ are convex (Table 1), considered as being patterns which disperse water and related to rapid runoff that make sudden floods during heavy rains, possibly constituting a negative hydrographic differential for the annual patterns of water

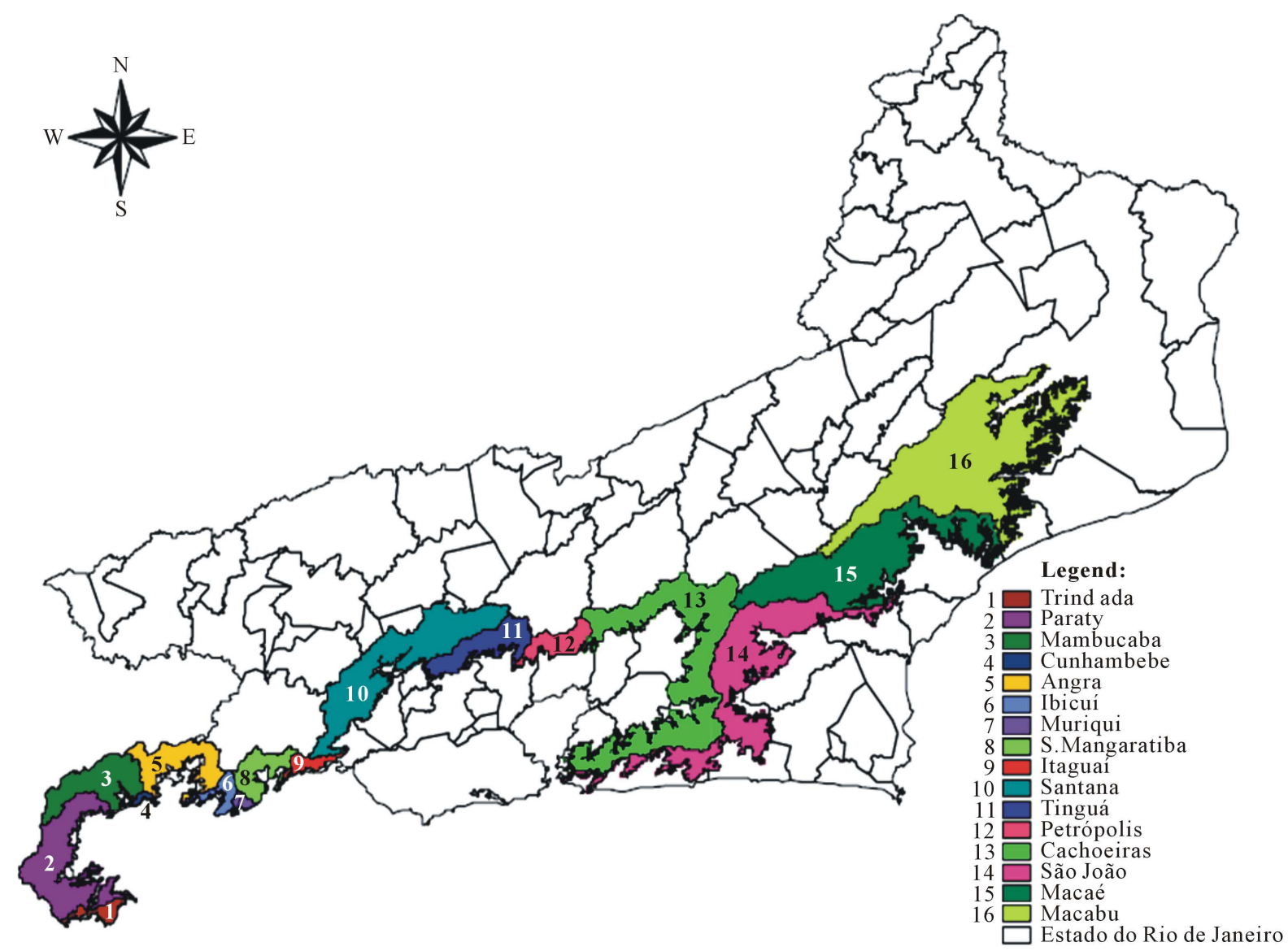

Figure 7. Distribution of air basins in the state of Rio de Janeiro. 
Table 1. Main variables distributed among different sectors of air basins.

\begin{tabular}{|c|c|c|c|c|c|c|c|c|c|c|c|c|c|}
\hline \multirow{2}{*}{\multicolumn{2}{|c|}{$\begin{array}{c}\text { Sector } \\
\text { Air basin }\end{array}$}} & \multicolumn{4}{|c|}{ Entrance } & \multicolumn{4}{|c|}{ Transmission/conduction } & \multicolumn{4}{|c|}{ Distribution } \\
\hline & & $\begin{array}{l}\text { Area } \\
\left(\mathrm{km}^{2}\right)\end{array}$ & $\begin{array}{c}\text { Distance } \\
\text { from } \\
\text { ocean } \\
(\mathrm{km})\end{array}$ & $\begin{array}{l}\text { Mouth } \\
(\mathrm{km})\end{array}$ & $\begin{array}{c}B^{\mathrm{a}} \\
\text { (angle) }\end{array}$ & $\begin{array}{l}\text { Slope area } \\
\left(\mathrm{km}^{2}\right)\end{array}$ & $\begin{array}{l}\text { Max. } \\
\text { altitude }\end{array}$ & $\begin{array}{c}\text { Declivity } \\
\text { (\%) }\end{array}$ & $\begin{array}{l}\text { Shape of } \\
\text { slope }\end{array}$ & $\begin{array}{r}\mathrm{LTR}^{\mathrm{b}} \\
(\mathrm{km})\end{array}$ & $\begin{array}{c}\text { Angle } \\
\text { (degree) }\end{array}$ & $\begin{array}{c}\text { Corridor } \\
\text { width } \\
(\mathrm{km})\end{array}$ & $\begin{array}{l}\text { Corridor } \\
\text { length } \\
\text { (upland) }\end{array}$ \\
\hline 1 & Trindade & 64.08 & 0.00 & 22.74 & 0.7 & 67.36 & 1070 & 30 & 2 & 52.99 & 0.7 & 4.77 & 0.00 \\
\hline 2 & Paraty & 916.03 & 6.66 & 27.37 & 0.3 & 567.44 & 1000 & 36 & 3 & 236.85 & 0.3 & 5.23 & 4.08 \\
\hline 3 & Mambucaba & 365.09 & 8.47 & 16.04 & 0.7 & 342.48 & 1000 & 23 & 3 & 58.73 & 0.7 & 4.00 & 5.56 \\
\hline 4 & Cunhambebe & 23.22 & 0.61 & 6.60 & 0.7 & 15.87 & 639 & 65 & 2 & 18.38 & 0.7 & 2.57 & 0.00 \\
\hline 5 & Angra & 446.57 & 6.97 & 7.11 & 1.0 & 301.18 & 1539 & 70 & 3 & 144.45 & 1.0 & 2.67 & 4.33 \\
\hline 6 & Ibicuí & 108.92 & 3.56 & 68.67 & 1.0 & 81.74 & 1692 & 60 & 3 & 73.07 & 1.0 & 8.29 & 1.67 \\
\hline 7 & Muriqui & 31.65 & 0.70 & 9.51 & 0.7 & 28.69 & 1125 & 45 & 2 & 13.66 & 0.7 & 30.80 & 0.00 \\
\hline 8 & S. Mangaratiba & 221.25 & 5.09 & 7.73 & 0.7 & 176.61 & 1599 & 70 & 2 & 67.12 & 0.7 & 2.78 & 2.83 \\
\hline 9 & Itaguaí & 76.89 & 7.60 & 24.78 & 0.7 & 69.36 & 1286 & 70 & 3 & 51.24 & 0.7 & 4.98 & 0.00 \\
\hline 10 & Santana & 1008.33 & 31.85 & 35.50 & 0.7 & 844.51 & 1776 & 20 & 2 & 215.84 & 0.7 & 5.96 & 26.21 \\
\hline 11 & Tinguá & 345.72 & 49.81 & 29.85 & 0.7 & 284.86 & 1756 & 65 & 3 & 197.58 & 0.7 & 5.46 & 42.75 \\
\hline 12 & Petrópolis & 194.55 & 14.36 & 24.95 & 0.7 & 159.80 & 2216 & 80 & 2 & 70.45 & 0.7 & 4.99 & 10.57 \\
\hline 13 & Cachoeiras & 2456.40 & 47.43 & 40.85 & 1.0 & 1226.02 & 2219 & 80 & 3 & 792.31 & 1.0 & 6.39 & 40.54 \\
\hline 14 & São João & 2191.04 & 54.09 & 128.02 & 0.7 & 1099.49 & 1719 & 75 & 3 & 900.34 & 0.7 & 11.31 & 46.74 \\
\hline 15 & Macaé & 1469.29 & 34.01 & 35.59 & 0.7 & 1209.53 & 1627 & 40 & 3 & 623.02 & 0.7 & 5.97 & 28.18 \\
\hline \multirow[t]{2}{*}{16} & Macabu & 1745.30 & 79.96 & 57.31 & 0.3 & 1878.34 & 1628 & 40 & 1 & 1492.15 & 0.3 & 7.57 & 71.02 \\
\hline & Total & 11664.32 & - & 542.62 & - & 8353.26 & - & - & - & 5008.18 & - & 86.03 & - \\
\hline
\end{tabular}

${ }^{\mathrm{a}}$ Angle of the entrance mouth; ${ }^{\mathrm{b}}$ Transition line of relief.

resources within the micro-basins. Another important result was that $94 \%$ of the air basins exceeded the maximum altitude at $1000 \mathrm{~m}$, which favors the condensation process of atmospheric water vapor through the orographic effect.

The most frequent entrance angle was from the Southeast (56\%), Southwest (38\%) and Northeast (6\%) (Table 1). This shows that air basins with their entrances turned toward the Southeast present more extensive drainage networks, demonstrating the effect of rainfall in relation to the relief and the catchment basins, reinforcing the macro-environmental characteristics to be constrained by the topography.

\subsection{Sectors Which Influence Wind Flow}

The state of Rio de Janeiro may be divided into quadrants related to the cardinal points (Southwest, Southeast, Northwest and Northeast). The first presents 11 air basins in the Southeast quadrant, one of the Southwest and Southeast quadrants, two in Northwest quadrant (facing in the same direction), and only one located in the Northeast quadrant coinciding with the orientation of its mouth, as shown in Table 1.

The data referring to the entrances of the air basins (Area, Distance from the Ocean, Mouth and Angle) showed Areas ranging from 23.22 to $2456.40 \mathrm{~km}^{2}$, while the Distance from the Atlantic Ocean varied from 0 to $79.96 \mathrm{~km}$. However, as the Angle parameter is closely related to the size of the Mouth, because it refers to the direction in which the mouth is turned, results showed that $69 \%$ of air basins are pointed to the South/Southeast (0.7), 19\% (1.0) toward the Southwest, and 12\% (0.3) to the Northeast.

The conduction data was organized into five main parameters (Slope Area, Altitude, Declivity, Slope Shape and LTR). The Slope Area presents variations between 15.87 and $1878.34 \mathrm{~km}^{2}$ (Table 1). It should be noted that 
there is an altitudinal gradient of 638 to 2219 meters from one end to the other of the Rio de Janeiro state, characterizing their regularity of the ridge line, and permitting air flow towards the catchment basin of the Paraíba do Sul river (sector of Distribution). This is justified because the ridge region allows the passage of air flow causing influences on the upper third of the adjacent catchment basins from the leeward air basins and situated in the foothills of the Serra do Mar.

\subsection{Cluster Analysis for Similarity in Environmental Attributes}

Though the results of the cluster analysis 5 groups of air basins were established (Table 2) with similar morphometric characteristics, shown in Figure 8.

With the level of homogeneity positioned at 58\% (Fenon line) of the Euclidian distance, two large groups of similar air basins were formed, where the angle (direction of line EF) was the discriminating factor, separating four (4) different angles: Southwest, South, Southeast and Northeast. The first was formed by the air basins represented by the numbers 12 and 10, located in the Southeast region, while the second was represented by basins numbered 13 (South/Southwest), 14 (South/Southeast), 15 (Southeast) and 16 situated in the Northeastern region of the state of Rio de Janeiro. This last basin is the only one sampled which is located in this part of the state, where the direction of its mouth coincides with its location; however, was the only basin that presented a pattern of convex slope.

The results also showed that the changes performed by physical and environmental factors within the groups were smaller than between them, made it possible to affirm that they maintain certain functional identities, which may be used to the systematize the identification of priority areas for the production of rainfall in the micro-basins. Thus, it should be noted that climate characteristics, such as speed and direction wind, as well as relative humidity, interfere directly in the volume of rainfall precipitated [34]. Therefore, these results may contribute to improve the public policy planning and zoning for the municipal master plans.

Table 2. Characterization of air basins in the state of Rio de Janeiro.

\begin{tabular}{ccccccc}
\hline \multirow{2}{*}{ Variable } & Unit of & \multicolumn{5}{c}{ Group } \\
\cline { 3 - 7 } & measurement & I & II & III & IV & V \\
\hline Basin/group & No. & 02 & 04 & 03 & 02 & 05 \\
Area & $\mathrm{km}^{2}$ & 1202.88 & 7902.03 & 172.62 & 1281.12 & 1122.46 \\
Declivity & $\%$ & 50 & 59 & 49 & 30 & 66 \\
Direction & - & SW & SW & SW/S & S/SW/SE & NE \\
\hline
\end{tabular}

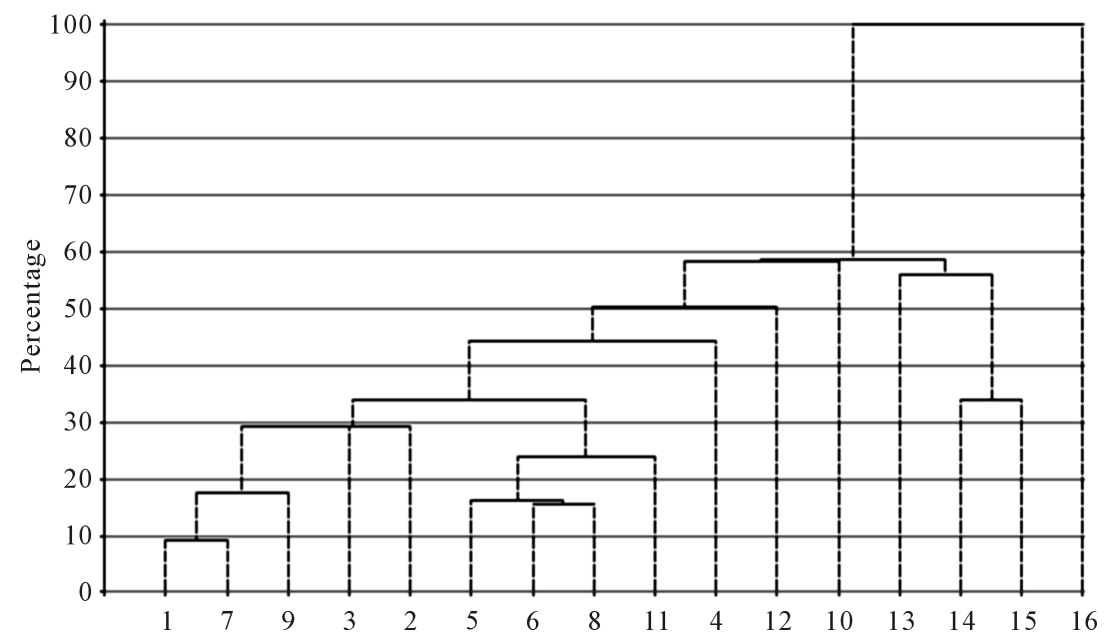

Figure 8. Cluster analysis of air basins of the state of Rio de Janeiro by affinity of morphometric factors. 
Furthermore, it can be observed that the Serra do Mar Mountain, with its three peaks (Pico Maior: $2336 \mathrm{~m}$; Pedra do Sino: $2310 \mathrm{~m}$; and Pico do Caledônia: $2252 \mathrm{~m}$ ) and various depressions, including valleys located along the ridge line, form strangulation zones (gorges) limiting the free circulation of air masses. These gorges have different shapes, morphometric characteristics and environmental functions, in which the vegetation may constitute a bio-indicator variable which integrates the effects of the differentiated supply of environmental attributes, as forests only occur and be sustained in places where there is enough water available in quantity and regularity to guarantee their survival.

Thus, the groups of air basins shown in Table 2 have functional identity between them, and should present similar environmental reactions, based on the movement of cold fronts, both on the water production and in environmental services provided to society.

\section{Conclusions}

The trajectory and intensity of the winds influence the landscape, and consequently, the formation and generation processes of water resources in the catchment basins throughout the mountain range of the Serra do Mar in Brazil. The windward (Atlantic) side, which receives the effects of the air basins directly, presents $20 \%$ of its structured area in 16 air basins, which, grouped together according to their similarity of morphometric factors, constitute 5 groups with distinct functional identities, based on their morphometric configurations: area, declivity, and direction of entrance of related air masses. These are divided into: I (2 units of air basins), II (4 units), III (3 units), IV (2 units), and V (5 units).

Indirectly, air basins interfere in the leeward areas, by way of the propagation of humid air masses through their escape zones, with both sides of the mountain ranges influenced by the same air basin and reaching all Brazilian states that are influenced from the ocean.

The use and territorial management of catchment basins in observance with the characteristics of air basins are an indispensable condition for sustainable environmental planning, because it facilitates the dissemination of good land use practices.

\section{Acknowledgements}

We wish to thank the Post-Graduate Program of Environmental and Forestry Sciences (PPGCAF) of the Federal Rural University of Rio de Janeiro (UFRRJ) for the opportunity to carry out this study.

\section{References}

[1] Chen, T.C., Chen, J.M. and Pjaendtner, J. (1995) Low Frequency Variations in the Atmospheric Branch of the Global Hydrological Cycle. Journal of Climate, 8, 92-107. http://dx.doi.org/10.1175/1520-0442(1995)008<0092:LFVITA>2.0.CO;2

[2] Ahrens, C.D. (2006) Meteorology Today: An Introduction to Weather, Climate and the Environment. 8th Edition, Cengage Learning, Boston.

[3] Holton, J.R. (1992) An Introduction to Dynamic Meteorology. 3rd Edition, Academic Press, San Diego.

[4] Peixoto, J.P. and Oort, A.H. (1992) Physics of Climate. American Institute of Physics, New York.

[5] Barry, R.G. and Chorley, R.J. (2010) Atmosphere, Weather and Climate. 9th Edition, Routledge, New York.

[6] Pereira, N., Ribeiro, A.L. and D’incao, F. (2011) Influência dos Fenômenos ENOS na Ocorrência de Frentes Frias no Litoral Sul do Brasil. Ciência e Natura, UFSM, 33, 91-99.

[7] Barbiére, E.B. and Kronemberger, D.M.P. (1994) Climatologia do litoral Sul-Sudeste do Estado do Rio de Janeiro. Cadernos de Geociências, Rio de Janeiro: FIBGE, 12, 57-73.

[8] Liebmann, B.P.S.D.R., Carvalho, L.A.S. and Jones, C. (2011) Moisture, Transport and Intraseasonal Variability in the South América Mossoon System. Climate Dynamics, 36, 1865-1880. http://dx.doi.org/10.1007/s00382-010-0806-2

[9] Chaves, R.R., Mitra, A.K. and Krishnamurti, T.N. (2005) Seasonal Climate Prediction for South America with FSU Multi-Model Synthetic Superensemble Algorithm. Meteorology and Atmospheric Physics, 89, 37-56. http://dx.doi.org/10.1007/s00703-005-0120-4

[10] Figueroa, S.N. and Nobre, C.A. (1990) Precipitation Distribution over Central and Western Tropical South America. Climanálise, 5, 36-45.

[11] Sun, D.Z. (2010) The Diabatic and Nonlinear Aspects of the El Niño-Southern Oscillation: Implications for Is Past 
and Future Behavior. In: Sun, D.Z. and Bryan, F., Eds., Climate Dynamics: Why Does Climate Vary? Geophysical Monograph Series, John Wiley and Sons Ltd., New York, 79-103.

[12] Businger, S., Graziano, T.M., Kaplan, M.L. and Rozumalski, R.A. (2005) Cold-Air Cyclogenesis along the GulfStream Front: Investigation of Diabatic Impacts on Cyclone Development, Frontal Structure, and Track. Meteorology and Atmospheric Physics, 88, 65-90. http://dx.doi.org/10.1007/s00703-003-0050-y

[13] Chen, S.H. and Lin, Y.L. (2005) Orographic Effects on a Conditionally Unstable Flow over an Idealized ThreeDimensional Mesoscale Mountain. Meteorology and Atmospheric Physics, 88, 1-21. http://dx.doi.org/10.1007/s00703-003-0047-6

[14] Cavelier, J., Solis, D. and Jaramilo, M.A. (1996) Fog Interception in Montane Forest across the Central Cordillera of Panamá. Journalof Tropical Ecology, 12, 357-369. http://dx.doi.org/10.1017/S026646740000955X

[15] Oliveira, J.L.F., Santos, I.A., Rosas, R.O. and Landau, L. (2006) Bacia Aérea III: Uma Unidade de Gerenciamento da Qualidade do Ar da Região Metropolitana do Rio de Janeiro. Anais do $2^{\circ}$ Congresso Acadêmico sobre Meio Ambiente e Desenvolvimento, UFF/FGV, Niterói.

[16] Weisburd, M.I. (1962) Air Pollution Control Field Operations Manual: A Guide for Inspection and Enforcement. US Department of Health, Education, and Welfare, Public Health Service, Division of Air Pollution, Washington DC.

[17] Balbinot, R., Oliveira, N.K., Vanzetto, S.C., Pedroso, K. andValerio, A.F. (2008) O Papel da Floresta no Ciclo Hidrológico em Bacias Hidrográficas. Revista Ambiência, 4, 131-149.

[18] Marques, J., Santos, J.M. and Salati, E.O. (1979) O Campo do Fluxo de Vapor D'água Atmosférico sobre a Região Amazônica. Acta Amazônica, 9, 701-713.

[19] Whiteman, C.D. (2000) Mountain Meteorology: Fundamentals and Applications. Oxford University, New York.

[20] Davis, E.G. and Naghettini, M.C. (2001) Estudo de chuvas intensas no Estado do Rio de Janeiro. Estudo Geoambiental de Estado do Rio de Janeiro. MME-CPRM, Brasília, 135 p.

[21] Nimer, E. (1979) Climatologia do Brasil. SUPREN and IBGE, Rio de Janeiro.

[22] Barboza, R.S. (2004) Interceptação Vertical na Serra do Mar do Rio de Janeiro, Nova Friburgo-RJ. Monograph (Degree in Forest Engineering), UFRRJ, Seropédica.

[23] Thornthwaite, C.W. and Mather, J.R. (1955) The Water Balance. Drexel Institute of Technology-Laboratory of Climatology, Publications in Climatology, Centerton, 104 p.

[24] Kjerfve, B., Ribeiro, C.H., Dias, G.T.M., Filippo, M. and Quaresma, V.S. (1997) Oceanographic Characteristics of an Impacted Coastal Bay: Baía de Guanabara, Rio de Janeiro, Brazil. Continental Shelf Research, 17, 1609-1643. http://dx.doi.org/10.1016/S0278-4343(97)00028-9

[25] INMET (2009) Normais Climatológicas do Brasil 1961-1990. Organizadores: Andrea Malheiros Ramos, Luiz André Rodrigues dos Santos, Lauro Tadeu Guimarães Fortes. INMET, Brasília/DF, Brasil.

[26] Pires, D.O. (2005) Inventário de Emissões Atmosféricas de Fontes Estacionárias e sua Contribuição para a Poluição do Ar na Região Metropolitana do Rio de Janeiro. Ph.D. Thesis, PPE/COPPE/UFRJ, 188 p.

[27] IBGE (2011) Bases Cartográficas. Instituto Brasileiro de Geografia e Estatística. http://mapas.ibge.gov.br/bases-e-referenciais/bases-cartograficas/cartas

[28] FIDERJ (1978) Indicadores Climatológicos do Estado do Rio de Janeiro. Fundação de Desenvolvimento Econômico e Social do Rio de Janeiro, Rio de Janeiro, 156 p.

[29] Sokal, R.R. and Rohlf, F.J. (1969) Biometry: The Principles and Practices of Statics in Biological Research. State University of New York, Stone Brook.

[30] Valentin, J.L. (2000) Ecologia Numérica: Uma Introdução á Análise Multivariada de Dados Ecológicos. Editora Interciência, Rio de Janeiro.

[31] Oksanen, J., Blanchet, F.G., Kindt, R., Legendre, P., Minchin, P.R., O’hara, R.B., Simpson, G.L., Solymos, P., Henry, M., Stevens, H. and Wagner, H. (2013) Vegan: Community Ecology Package. R Package Version 2.0-7. http://CRAN.R-project.org/package=vegan

[32] R Core Team (2013) R: A Language and Environment for Statistical Computing. R Foundation for Statistical Computing, Vienna.

[33] Barboza, R.S. (2007) Caracterização das Bacias Aéreas e Avaliação da Chuva Oculta nos Contrafortes da Serra do Mar — RJ. Master Degree, PPGCAF/UFRRJ, Seropédica.

[34] Singh, R.P. (1987) Rainfall Interception by Pinus Wallichiana Plantation in Temperate Region of Himachal Pradesh, India. Indian Forester, 104, 559-566. 